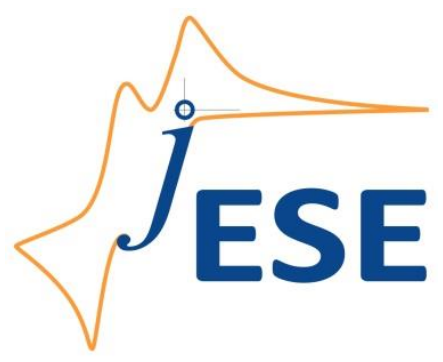

Open Access : : ISSN 1847-9286

www.jESE-online.org

Original scientific paper

\title{
Electrochemical oxidation of amoxicillin in its pharmaceutical formulation at boron doped diamond (BDD) electrode
}

\author{
Gnamba Corneil Quand-Même, Appia Foffié Thiéry Auguste, \\ Loba Evelyne Marie Hélène, Sanogo Ibrahima*, Ouattara Lassine ${ }^{凶}$ \\ Laboratoire de chimie physique, UFR SSMT, Université Félix Houphouët-Boigny de Cocody, Abidjan, \\ 22 BP 582 Abidjan 22, Côte d'Ivoire \\ *Centre Hospitalier Universitaire (CHU) de Treichville, Abidjan, 01 BP V3 Abidjan 01, Côte d'Ivoire \\ Corresponding Author: ouatlassine@yahoo.fr ; Tel: +22502143382
}

Received: May 13, 2015; Revised: July 25, 2015; Published: August 26, 2015

\begin{abstract}
In this work, voltammetric and electrolysis experiments have been carried out on a conductive boron doped diamond (BDD) electrode in a solution containing amoxicillin in its pharmaceutical formulation. The physical characterization of the BDD surface by scanning electron microscopy (SEM) reveals a polycrystalline structure with grain sizes ranging between 0.3 and $0.6 \mu \mathrm{m}$. With Raman spectroscopy, BDD surface is composed of diamond type carbon $\left(C_{s} p^{3}\right)$ and graphitic type carbon $\left(C s p^{2}\right)$. The XPS survey of the BDD surface has revealed the presence of $C 1 \mathrm{~s}$ and $O 1 \mathrm{~s}$. The deconvolution of the C1s spectrum showed that the BDD surface chemical bonds were composed by $\mathrm{C}-\mathrm{C}$ and $\mathrm{C}-\mathrm{H}$. The ferri/ferrocyanide redox couple showed a quasi reversible behavior on BDD and $B D D$ showed a quasi metallic properties with a good electrical contact between the diamond coating and the silicono substrate. The electrochemical characterization of the BDD electrode in sulfuric acid electrolyte showed a wide potential window of $2.74 \mathrm{~V}$. The oxidation of amoxicillin showed an irreversible anodic wave on the voltammogram in the domain of water stability indicating a direct oxidation of amoxicillin at BDD surface. The treatment of amoxicillin in the synthetic wastewaters under various constant current densities $20,50,100,135 \mathrm{~mA} \mathrm{~cm}^{-2}$ on BDD showed that amoxicillin is highly reduced under $100 \mathrm{~mA} \mathrm{~cm}{ }^{-2}$ reaching $92 \%$ of the chemical Oxygen demand (COD) removal after $5 \mathrm{~h}$ of electrolysis. Investigation performed in perchloric acid as supporting electrolyte led to $87 \%$ of COD removal after $5 \mathrm{~h}$ of electrolysis. Mineralization of amoxicillin occurs on BDD and the COD removal was higher in sulfuric acid than in perchloric acid owing to the involvement of the in-situ formed persulfate and perchlorate to the degradation process mainly in the bulk of the solution. The instantaneous current efficiency (ICE) presents an exponential decay indicating that the process was limited by diffusion. The specific energy consumed after $5 \mathrm{~h}$ of the amoxicillin electrolysis was $0.096 \mathrm{kWh} \mathrm{COD}^{-1}$ and $0.035 \mathrm{kWh}$ $C O D^{-1}$ in sulfuric acid and in perchloric acid respectively.
\end{abstract}

\section{Keywords}

Boron doped diamond, Amoxicillin, Electrolysis, Anodic oxidation, Hospital wastewater 


\section{Introduction}

Antibiotics, one of the most widely used and prescribed pharmaceuticals, are applied for killing microbes [1-3]. Recently the wide occurrence of antibiotics in groundwater raised concerns about potential adverse on human health and aquatic ecosystem [4-7]. In Côte d'Ivoire, the consumption of antibiotic per year is huge especially for hospitalized patients. The occurrence of antibiotics in natural water is due to the lack of effective treatment of the wastewaters containing such medicines. That is the case of the teaching hospitals of Côte d'Ivoire where the wastewater treatment plant built in the former days precisely in the last four decades do not operate anymore. Thus, the hospital wastewaters are directly rejected in the environment without treatment. The presence of antibiotics in the aquatic environment even at very low concentration levels can promote the growth of antibiotic resistant bacteria or pathogens [8-10]. Antiobotics are found to be resistant to biological degradation processes, escaping almost intact from conventional wastewater treatment plants. Among antibiotics, amoxicillin, one of the most used drug worldwide, has been detected in surface waters and showed a resistance to biological treatment $[11,12]$. So a promishing approach to the remediation of wastewaters contaminated with high contents of this antibiotic is the application of innovative techniques such advanced oxidation processes [13-16]. Advanced oxidation processes are characterized by the production of extremely reactive and unselective hydroxyl radicals which is able to oxidize and mineralize almost all organic compounds to $\mathrm{CO}_{2}$ and water. As advanced oxidation process, ozonation has been used for amoxicillin oxidation and that resulted in a very low mineralization degree [17]. With PhotoFenton methods, stable intermediates are formed and they further undergo difficult mineralization [18]. Among these advanced oxidation processes to be used for drugs removal, electrochemical advanced oxidation processes (EAOPr) are very attractive for wastewater decontamination without a need of addition of toxic chemical reagents and also without producing dangerous wastes. Among EAOPr, anodic oxidation is the most effective technique. It consists in the destruction of pollutants by hydroxyl radicals generated from water oxidation at the surface of the anode $[19,20]$. In such a way, oxide anodes like tin dioxide have successfully been used for amoxicillin oxidation but less than $80 \%$ mineralization is found after $24 \mathrm{~h}$ of electrolysis [21]. Thus, great attention for wastewater treatment was paid on the use of boron doped diamond (BDD) electrodes which have been found to be effective for various organic compound oxidation $[22,23]$. In fact, the use of boron doped diamond is based on its physical and chemical properties such as surface inertness with low adsorption capability and surface corrosion stability. Boron doped diamond (BDD) thin films are usually prepared for water remediation since they produce very high amount of weakly physisorbed hydroxyl radicals. Due to these properties, it has been used for electrosynthesis, electroanalysis, and electrochemical combustion [23]. Boron doped diamond has been successfully used for real and synthetic industrial wastewater treatment [2325]. In the aim of contributing to the treatment of the hospital wastewater in Côte d'Ivoire especially in the teaching hospitals, the investigation of the electrochemical treatment of a simulated wastewater of amoxicillin in its pharmaceutical formulation has been carried out on boron doped diamond. In this work, voltammetric and electrolysis techniques have been employed in conditions where several experimental parameters have been varied

\section{Experimental}

Boron doped diamond (BDD) electrodes were prepared by hot-filament chemical vapor deposition (HF-CVD) on low resistivity (1-3 $\mathrm{m} \Omega \mathrm{cm}$ ) p-Si wafers (siltronix, diameter $10 \mathrm{~cm}$, 
thickness $0.5 \mathrm{~mm}$ ). The process gas was a mixture of $1 \% \mathrm{CH}_{4}$ in $\mathrm{H}_{2}$ containing trimethylboron. Film growth occurred at a rate of $0.24 \mu \mathrm{m} \mathrm{h}^{-1}$. The film thickness was about $1 \mu \mathrm{m}$. More details concerning the preparation of BDD electrodes are given elsewhere $[26,27]$. The scanning electron microscopy (SEM) images of the BDD electrode were taken with a JEOL LMS-6300-F instrument. The Raman spectrum of the BDD electrode was obtained at room temperature with a Renishaw RM 1000 Raman spectrometer. X-ray photoelectron spectrum of the diamond film was recorded with a Kratos Axis-ultra spectrometer with a monochromatic Al K $\alpha$ X-ray source operated at $15 \mathrm{kV}$ with pass energy of $20 \mathrm{eV}$. The carbon $1 \mathrm{~s}$ spectrum has been deconvoluted using the CasaXPS computer program. The voltammetric measurements were performed in a three-electrodes electrochemical cell using a voltalab PGP 201 (voltamaster 1 as software). The counter electrode (CE) was a platinum wire and the reference electrode (RE) was a saturated calomel electrode (SCE). To overcome the potential ohmic drop, the reference electrode was mounted in a luggin capillary and placed close to the working electrode by a distance of $1 \mathrm{~mm}$. The apparent exposed area of the working electrode was $1 \mathrm{~cm}^{2}$. For the exhaustive electrolysis, a batch reactor was used. The synthetic amoxicillin wastewater was fed to the reactor by a peristaltic pump with a flow rate of $2.08 \mathrm{~mL} \mathrm{~s}^{-1}$. The exposed electrode surface area with the solution was about $16 \mathrm{~cm}^{2}$. The chemicals used in this work composed of $\mathrm{H}_{2} \mathrm{SO}_{4}$ (Fluka), $\mathrm{HClO}_{4}$ (Fluka), $\mathrm{K}_{3} \mathrm{Fe}(\mathrm{CN})_{6}$ (Fluka), $\mathrm{K}_{4} \mathrm{Fe}(\mathrm{CN})_{6}$ (Fluka) and amoxicillin tablets (from a pharmacy in Abidjan). All the chemicals were used as received without any further treatment for the experiment. All the solutions used in the current work were prepared with distilled water. All the electrochemical experiments were made at ambient temperature of $25^{\circ} \mathrm{C}$.

\section{Results and discussion}

Physical characterization of the Boron Doped Diamond (BDD) electrode

Figure 1 shows the scanning electron microscopic image of the boron doped diamond electrode.

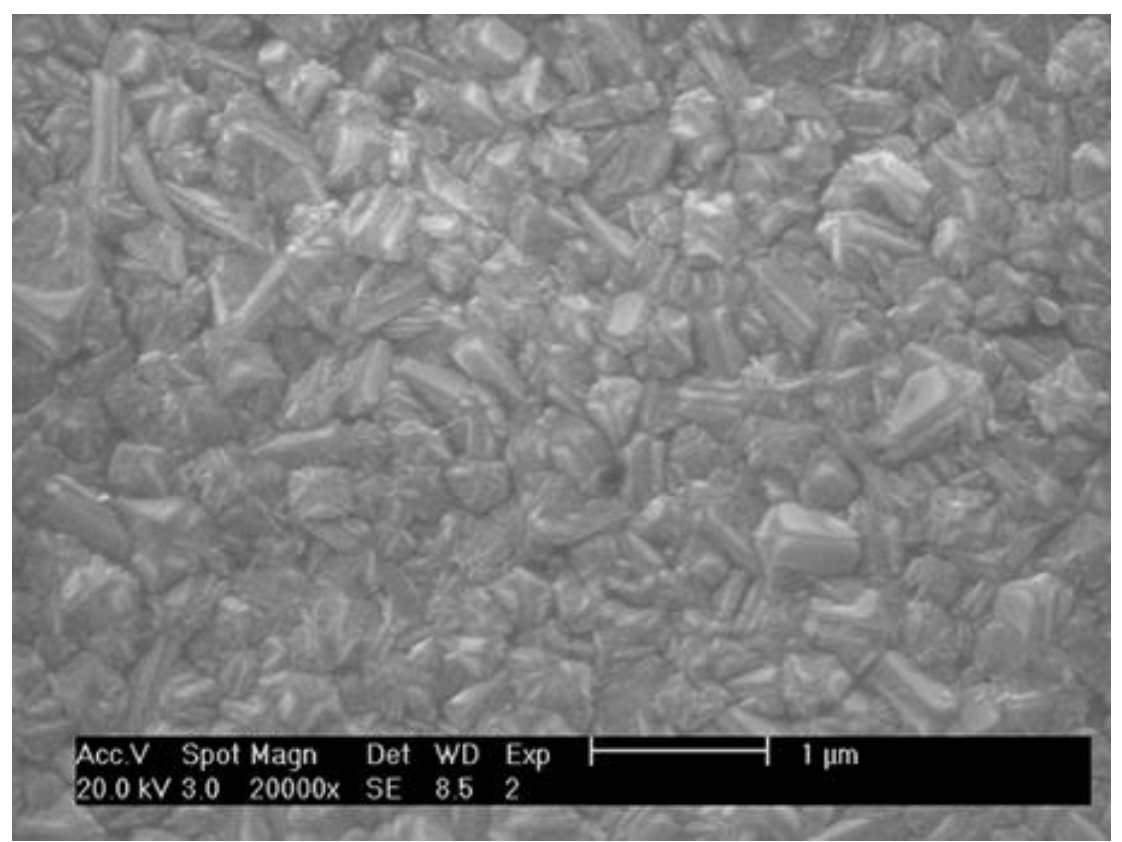

Figure 1. Micrograph of boron doped diamond

The image indicates that BDD presents a polycrystalline structure [28]. The morphological grains sizes are ranging between 0.3 and $0.6 \mu \mathrm{m}$. The grains are heavily twinned. At the bottom of 
the diamond grains, a relative dark space was observed especially at grains boundary which can be related probably to graphitic carbon $\left(\mathrm{Csp}^{2}\right)$ formed during the BDD preparation.

Figure 2 shows the Raman spectrum of the BDD sample excited by the $514.5 \mathrm{~nm}$ laser. A narrow peak at $500 \mathrm{~cm}^{-1}$ corresponding to Silicon signal was observed. A narrow peak at $1332 \mathrm{~cm}^{-1}$ is characteristic of the diamond $\left(\mathrm{Csp}^{3}\right)$ crystal signal and a broad band centered at $1550 \mathrm{~cm}^{-1}$ corresponds to the non-diamond carbon impurities $\left(\mathrm{Csp}^{2}\right)$. That finding indicates that the graphitic type carbon is present on the boron doped electrode probably in the diamond grains boundaries.

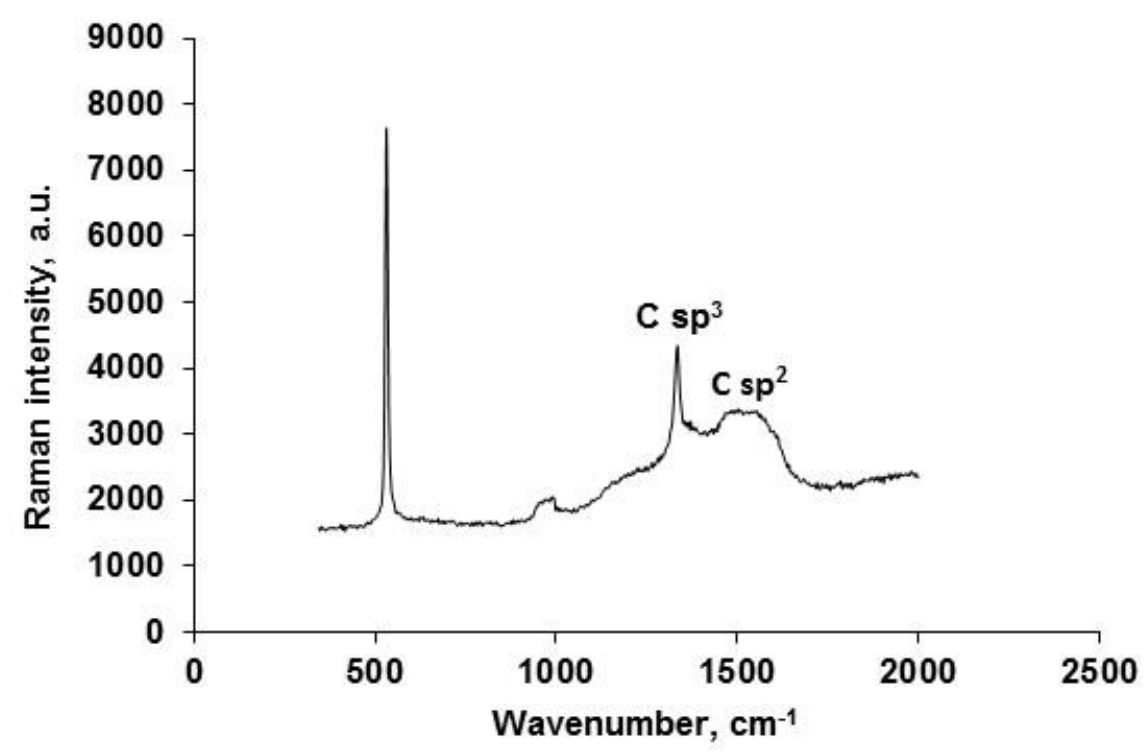

Figure 2. Raman spectroscopy spectrum of the BDD electrode

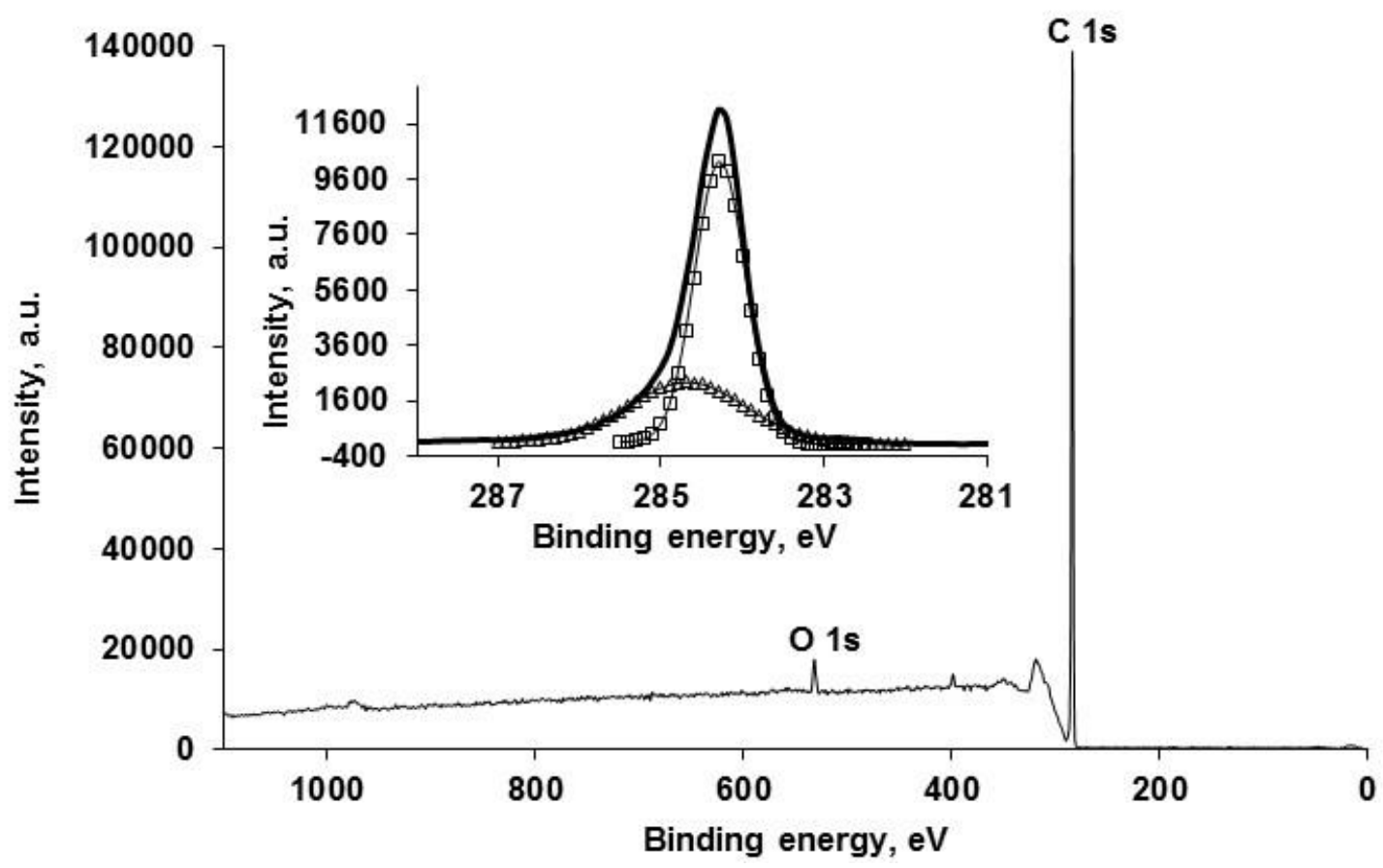

Figure 3: XPS spectrum of the as prepared BDD electrode. Inset : deconvoluted XPS C 1s of BDD

Figure 3 shows the XPS spectrum of the BDD film. That survey presents the same trend as that found in literature for other BDD electrodes [29,30]. The elemental composition of the BDD surface has been given. The spectrum is dominated by a sharp peak located at $285 \mathrm{eV}$ 
corresponding to $C 1 s[29,30]$. A small peak related to $O 1$ s has been observed at $532.5 \mathrm{eV}$. The ratio of $\mathrm{O} / \mathrm{C}$ is about 0.209 indicating that there is a very low amount of oxygen at the surface of the as grown BDD electrode. The surface chemical bonds have been checked through the deconvolution of $\mathrm{C} 1 \mathrm{~s}$ spectra. The obtained result is inserted in Figure 3 . The deconvolution of the parent C 1s spectrum led to two peaks. One located at $284.2 \mathrm{eV}$ and the other one at $284.7 \mathrm{eV}$ corresponding to the sharp and the broad peak presented respectively in the $C 1$ spectrum (inset of Figure 3). The main peak located at $248.2 \mathrm{eV}$ could be assigned to $\mathrm{C}-\mathrm{C}$ bonds and that located at $284.7 \mathrm{eV}$ could be assigned to $\mathrm{C}-\mathrm{H}$ bonds $[29,30]$.

\section{Cyclic voltammetry}

Figure 4 shows the voltammetric i-E curves of boron doped diamond in $100 \mathrm{mM}$ (equimolar) ferri/ferrocyanide $\left(\left[\mathrm{Fe}(\mathrm{CN})_{6}\right]^{3-} /\left[\mathrm{Fe}(\mathrm{CN})_{6}\right]^{4-}\right)$ in $0.1 \mathrm{M} \mathrm{KOH}$ at various potential scan rates ranging between $120 \mathrm{mV} \mathrm{min}^{-1}$ and $480 \mathrm{mV} \mathrm{min}^{-1}$. In this Figure, the observed anodic and a cathodic peaks correspond to the oxidation and reduction of the redox couple, respectively. The observed peaks are typical for such redox couple on various good conductors electrodes [31,32]. The increase in the potential scan rates leads to an increase of the peak current values. The separation between the potential of the anodic and cathodic current peaks, $\Delta E_{\mathrm{p}}$, increases slightly with the increase of the potential scan rates investigated and amounts to $276 \mathrm{mV}$ for the scan rate of $120 \mathrm{mV} \mathrm{min}{ }^{-1}$ i.e. $2 \mathrm{mV} \mathrm{s}^{-1}$ which is the lowest observed $\Delta E_{\mathrm{p}}$ value determined in this work. The value is higher than the $60 \mathrm{mV}$ expected for the fast and reversible system. This could either be due to a slow electrontransfer reaction at the BDD electrode/solution interface or possibly due to the intrinsic semiconducting properties of the diamond. Moreover, the absolute values of the ratios of the anodic current peak density over the cathodic current peak densities are about $\left|j_{p a} / j_{p c}\right|=1.046 \pm 0.021$ which is an indication of the reversibility of the electrode process. From the curves, the current of the peaks were plotted against the square root of the potential scan rates and a linear trend was obtained for both the anodic and cathodic peaks. The slopes of the straigth lines were almost the same in both cases and were about $\left(25.7 \mathrm{~mA} \mathrm{~cm}^{-2} \mathrm{~s}^{1 / 2} \mathrm{~V}^{-1 / 2}, R^{2}=0.9994\right)$ and ( $\left.25.5 \mathrm{~mA} \mathrm{~cm}^{-2} \mathrm{~s}^{1 / 2} \mathrm{~V}^{-1 / 2}, R^{2}=0.998\right)$ for the anodic and the cathodic straigth lines respectively. The linear relationship between the response current and the square root of the potential scan rate indicates that the redox kinetics at the boron-doped diamond electrode is a planar diffusioncontrolled process.

The overall obtained results indicated eventually that the redox couple behaves in a quasireversible manner at the boron doped diamond and also demonstrated the formation of a good electric contact between the substrate in silicon and the diamond coating [31,32].

Figure 5 gives the voltammetric curves recorded on BDD for various concentrations of the redox couple at $480 \mathrm{mV} \mathrm{min}^{-1}$. The height of the peak current increases as the concentration of the redox couple increases. Plotting the cathodic and the anodic peak current against the redox couple's concentration, a linear evolution is obtained. For both the cathodic and anodic peak current investigated, straigth lines lead to the same slope $2.10^{-2} \mathrm{~mA} \mathrm{~cm} \mathrm{mM}^{-1}, R^{2}=0.99$. The current results confirm the fact that the boron doped diamond in use behaves as a quasi-metallic material with the tendancy to be irreversible towards the ferri/ferrocyanide redox couple compared to metallic electrodes such as platinum electrode.

That metallic behavior of the BDD can be related to the content of boron in the BDD's lattice and also to the involvement in the overall processes of all the boron doped diamond surface components such as diamond $\left(\mathrm{Csp}^{3}\right)$ and non-diamond carbon $\left(\mathrm{Csp}^{2}\right)$ at the diamond grain 
boundaries [33]. Finally, the boron doped diamond used in this work showed an acceptable electrical conductivity that can ensure electrochemical measurements and can be used for pharmaceutical product investigation.

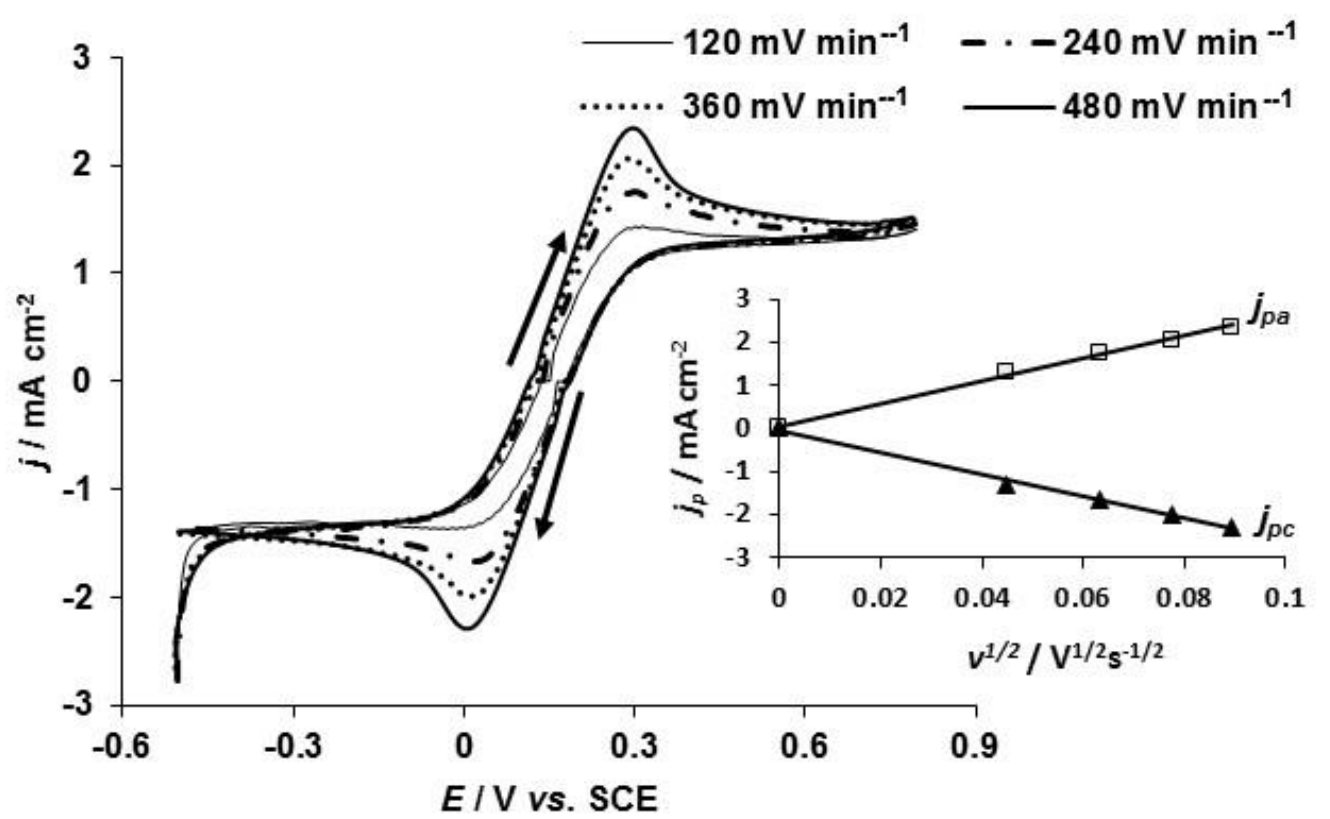

Figure 4 : Cyclic voltammetric curves of ferri/ferrocyanide on boron doped diamond electrode at various potential scan rates $\left(120 \mathrm{mV} \mathrm{min}^{-1}-480 \mathrm{mV} \mathrm{min}^{-1}\right), \mathrm{C}=100 \mathrm{mM}, \mathrm{T}=25^{\circ} \mathrm{C}, \mathrm{CE}: \mathrm{Pt}$, $R E: S C E$, in the inset: evolution of current peak against square root of potential scan rates

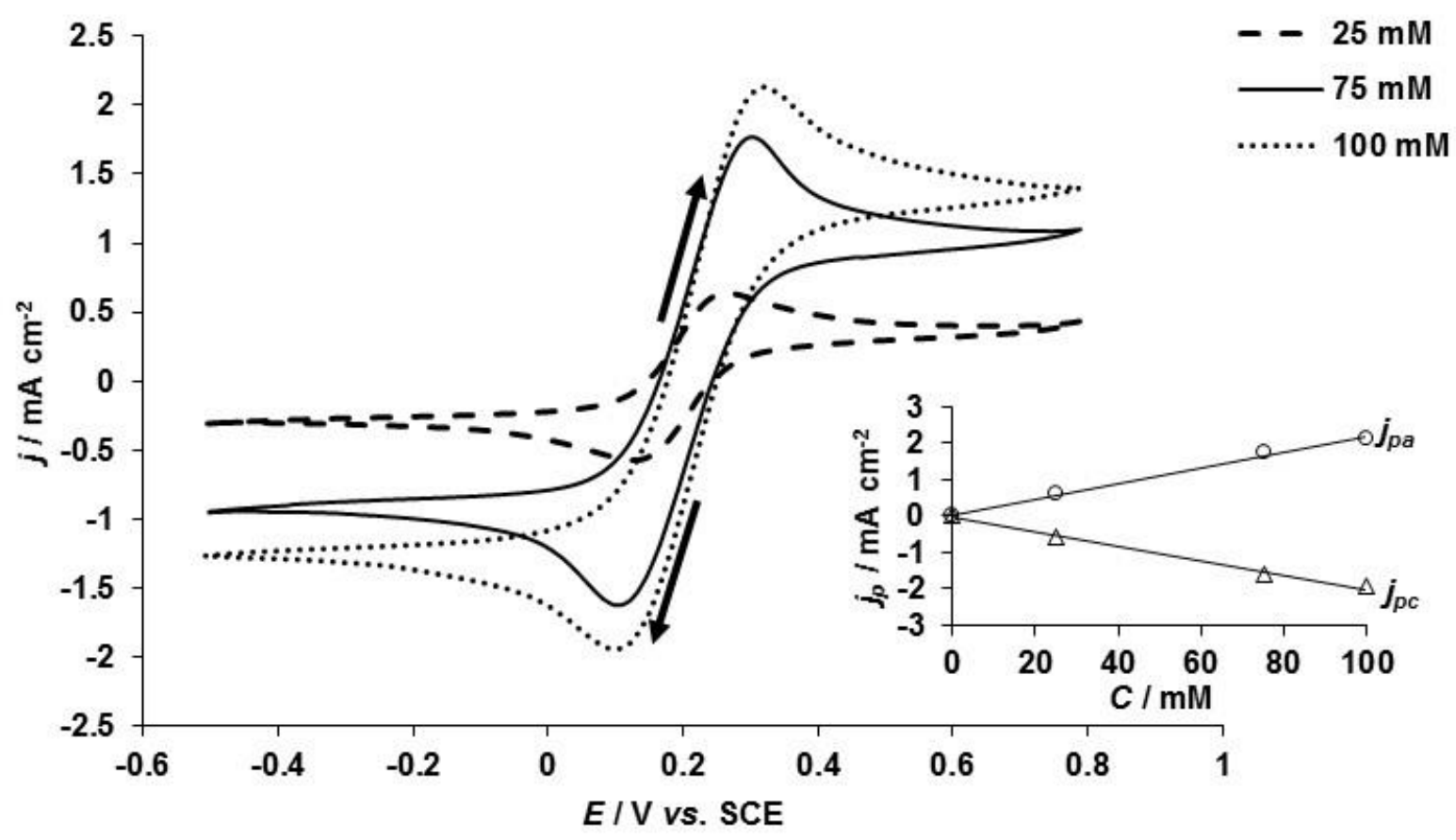

Figure 5 : Cyclic voltammetric curves of ferri/ferrocyanide on boron doped diamond electrode at various redox couple concentration at $480 \mathrm{mV} \mathrm{min}^{-1}, \mathrm{~T}=25^{\circ} \mathrm{C}, \mathrm{CE}: \mathrm{Pt}, \mathrm{RE}$ : SCE, in the inset : evolution of current peak against redox couple concentration

Figure 6 presents the voltammetric curves recorded on boron doped diamond at a low potential scan rate $\left(480 \mathrm{mV} \mathrm{min}^{-1}\right)$ in sulfuric acid free or containing $1 \mathrm{~g} \mathrm{~L}^{-1}$ amoxicillin. In absence 
of amoxicillin, the obtained voltammogram showed a wide potential window of $\Delta E=2.74 \mathrm{~V}$ between the onset of the potentials of the oxygen evolution reaction (OER) and the hydrogen evolution reaction (HER). Close to the onset of the OER, an oxidation wave is observed. According to literature, that wave could be related to the oxidation of surface redox species such as $\mathrm{Csp}^{2}$ especially surface quinone functional group [34].

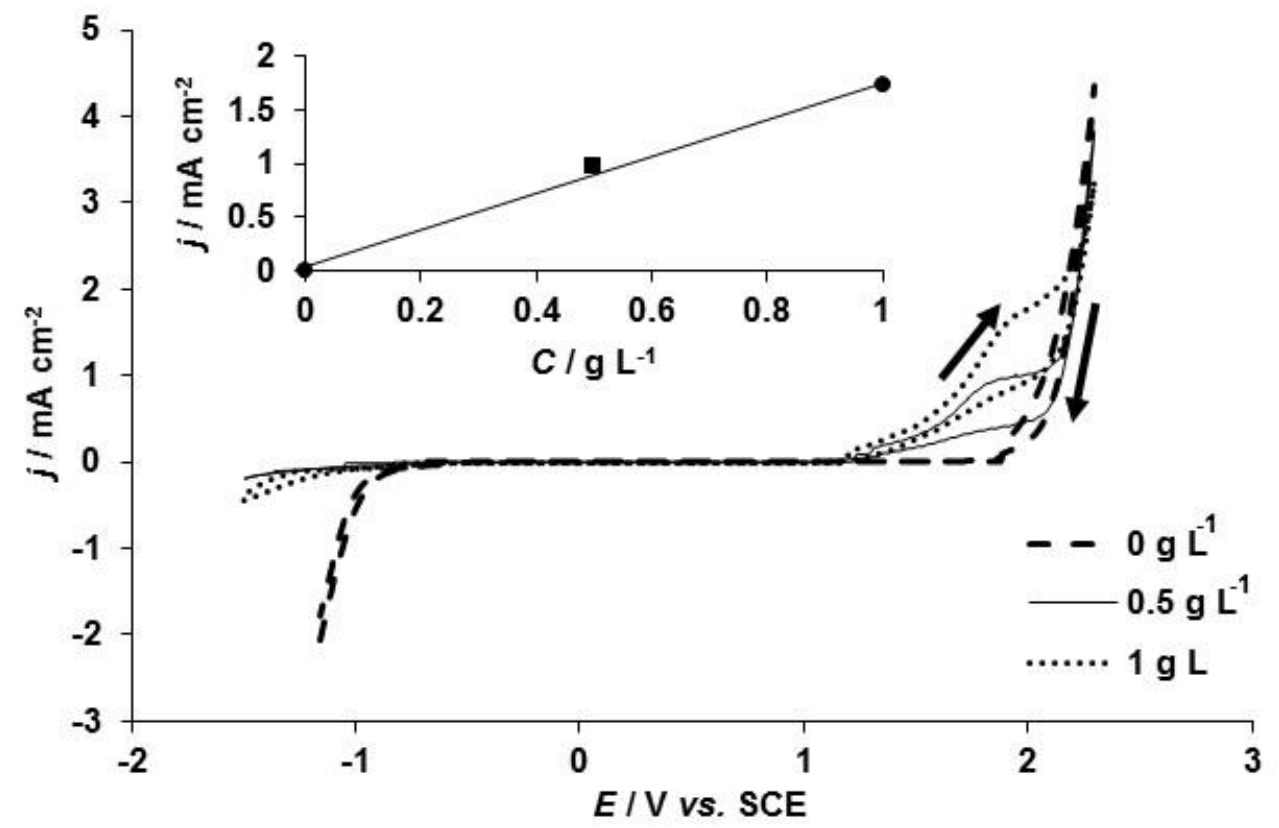

Figure 6. Cyclic voltammetry curves recorded on boron doped diamond electrodes in several concentration of amoxicillin containing sulfuric acid electrolyte at $480 \mathrm{mV} / \mathrm{min}, \mathrm{CE}: \mathrm{Pt}, \mathrm{T}=25^{\circ} \mathrm{C}$, RE: SCE. Inset: plot of current density of amoxicillin oxidation wave versus amoxicillin concentration at $1.9 \mathrm{~V}$

In the presence of amoxicillin, change in the voltammogram is observed and the current starts to increase at about $1.2 \mathrm{~V}$ vs. SCE followed by an irreversible anodic wave at about $1.8 \mathrm{~V} v$ v. SCE. The observed wave is characteristic of the anodic oxidation of amoxicillin. Moreover, as the concentration of the amoxicillin increases, the height of the wave increases too. This results evidenced a direct oxidation of amoxicillin in the electrochemical window of water stability at BDD. The oxidation of amoxicillin at high potential close to OER could have been catalyzed by $\mathrm{Csp}^{2}$ presents at the BDD's grain boundaries. In the inset of Figure 6, the current recorded at $1.9 \mathrm{~V} v \mathrm{~s}$. SCE on the wave was plotted against the concentration of the amoxicillin. One observes a linear relationship of the current versus concentration $(I-C)$ curve with a slope of $1.7 \mathrm{~mA} \mathrm{~cm} \mathrm{~L} \mathrm{~g}^{-1}$, $\mathrm{R}^{2}=0.99$. Successive scans have been performed at $480 \mathrm{mV} \mathrm{min}^{-1}$ on the BDD electrode and the results are presented in Figure 7. One observed well superimposed curves in the anodic potential domain while a decrease of the cathodic current in absolute values leading to the increase of the onset of the hydrogen evolution reaction potential was found. This finding could indicate the formation of a polymeric film at the investigated electrode's surface which, during the backwards of the potential scan in the negative direction, inhibited the HER.

Varying the potential scan rates, Figure 8 was obtained. The oxidation wave of amoxicillin increases with the potential scan rate. Moreover, plotting the current recorded at $1.9 \mathrm{~V}$ vs. SCE against the square root of the potential scan rates, a linear relationship was obtained indicating that the amoxicillin oxidation process was diffusion controlled. The obtained straight line has a slope of $17 \mathrm{~mA} \mathrm{~cm}^{-2} \mathrm{~s}^{1 / 2} \mathrm{~V}^{-1 / 2}, R^{2}=0.9996$. 


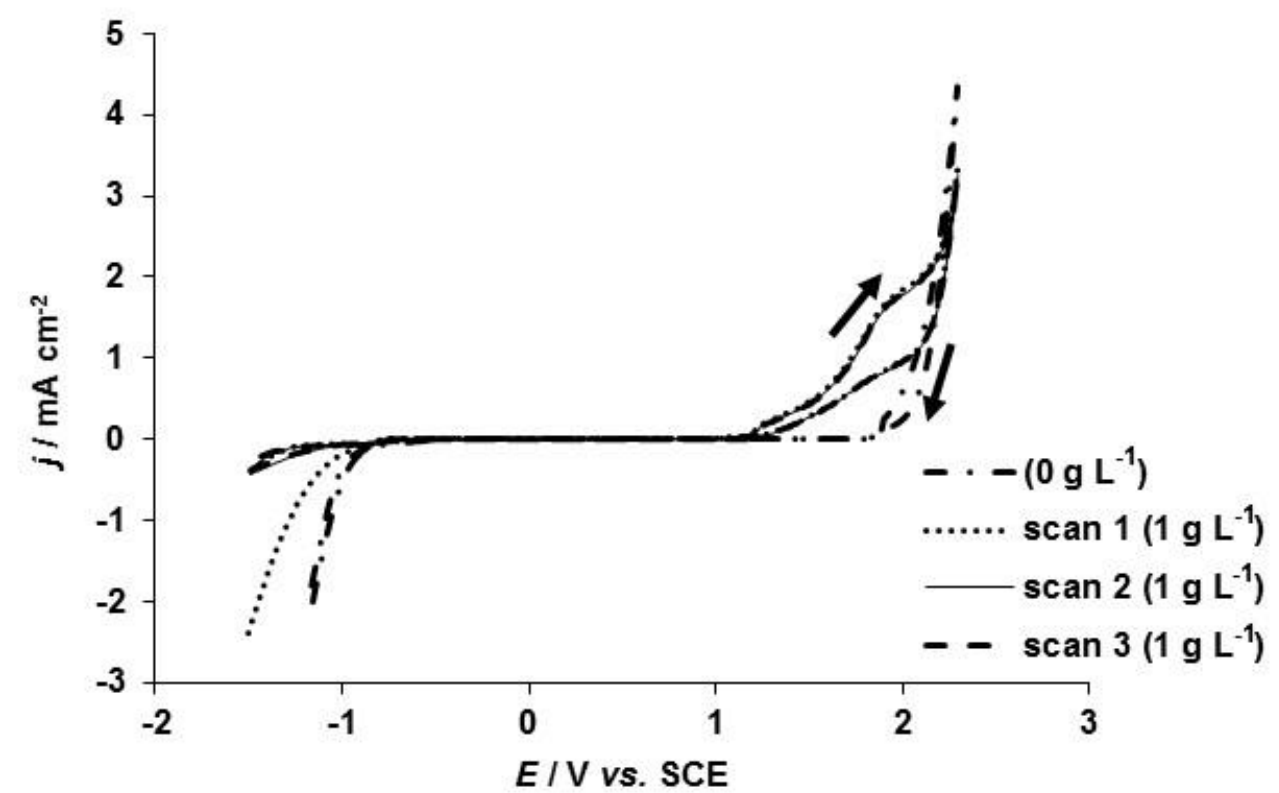

Figure 7. Cyclic voltammetry curves recorded on boron doped diamond electrodes in several successive scans in $1 \mathrm{~g} \mathrm{~L}^{-1}$ of amoxicillin containing $0.1 \mathrm{M}$ sulfuric acide electrolyte at $480 \mathrm{mV} \mathrm{min}^{-1}, \mathrm{CE}: \mathrm{Pt}, \mathrm{T}=25^{\circ} \mathrm{C}, \mathrm{RE}: \mathrm{SCE}$.

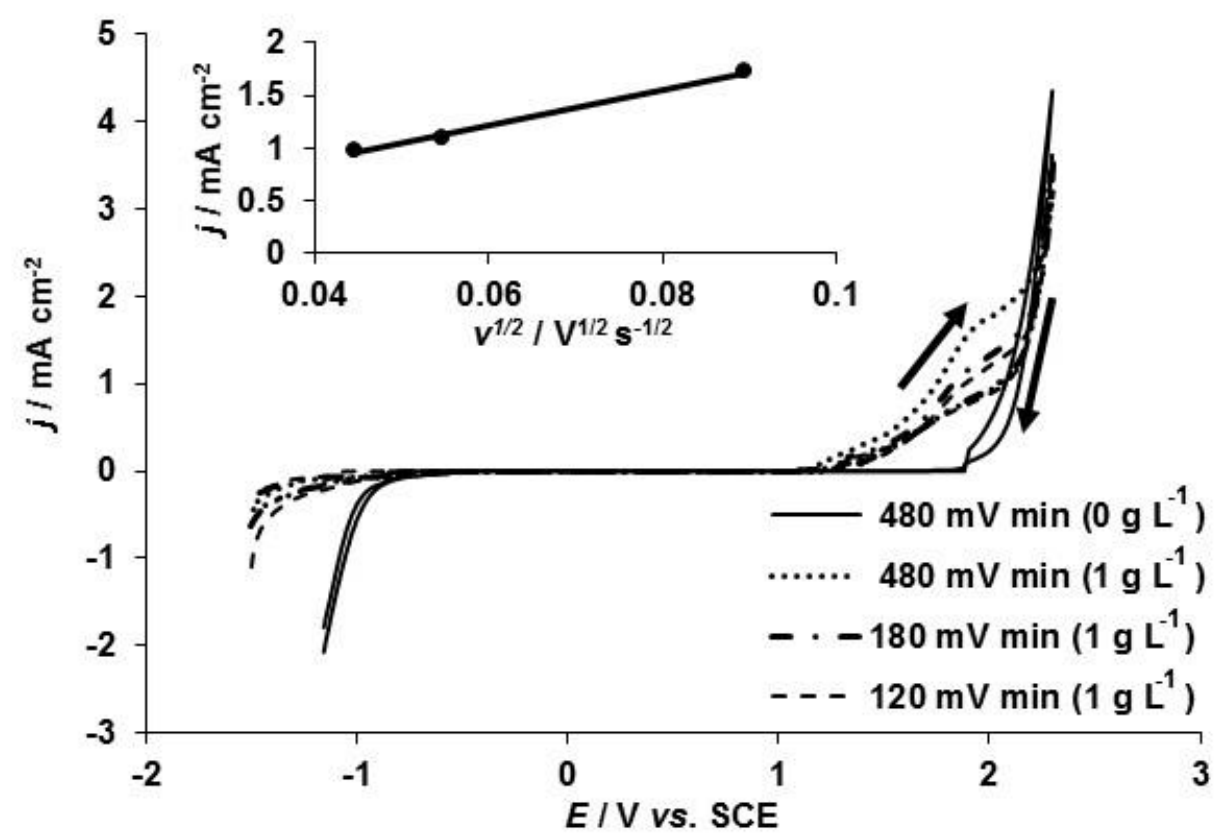

Figure 8. Cyclic voltammetry curves recorded on boron doped diamond electrodes in $1 \mathrm{gL}^{-1}$ of amoxicillin containing $0.1 \mathrm{M}$ sulfuric acid electrolyte at several potential scan rates, CE: Pt, $\mathrm{T}=25^{\circ} \mathrm{C}, R E$ : SCE. in the inset : evolution of currents density recorded at $1.9 \mathrm{~V}$ against the square root of the potential scan rates

\section{Bulk electrolysis}

For the bulk electrolysis of the amoxicillin in sulfuric acid, an undivided reactor has been used under galvanostatic regime. The system worked under a batch operation mode. The simulated wastewater was fed into the electrochemical reactor at a flow rate of $2.08 \mathrm{~mL} \mathrm{~s}$. The mass transfer coefficient determined using the ferri/ferrocyanide redox couple was $2.36 \times 10^{-7} \mathrm{~m} \mathrm{~s}^{-1}$. The calculated initial current density using equation (1) [35] is about $6.0 \mathrm{~mA} \mathrm{~cm}$. 


$$
l_{\lim }=4 F k_{\mathrm{d}} A C O D
$$

with $F=96500 \mathrm{C}, k_{\mathrm{d}}$ is the mass transfer coefficient, $A$ is the electrode surface area in the contact with the solution, COD is the chemical oxygen demand.

According to the work of Michaud and coworkers [35], two main regimes can be reached depending on the applied current compared to the initial limiting current.

If $I<l_{\text {lim }}$ a galvanostatic process governs the overall oxidation process i.e. limited by charge transfer reaction. If $I<l_{\text {lim, }}$ the oxidation process is mass transfer controlled i.e. limited by diffusion.

In the current case, the imposed current densities ranging from 20-135 $\mathrm{mA} \mathrm{cm}^{-2}$ are higher than the initial limiting current density. The obtained results are presented in Figure 9. It appears that the normalized COD (Equation 2) decreases with time for the investigated current densities. That decrease follows an exponential trend like what has been described eleswhere [35] when applied current density was higher than the initial limited current density. The process is under mass transport control. The abatment rate of the chemical oxygen demand (COD) increases from $20 \mathrm{~mA} \mathrm{~cm}{ }^{-2}$ to $100 \mathrm{~mA} \mathrm{~cm}{ }^{-2}$ and then decreases from $100 \mathrm{~mA} \mathrm{~cm}$ to $135 \mathrm{~mA} \mathrm{~cm}{ }^{-2}$. That observation is highlighted in Figure 10 where the COD abatement rate determined after $4 \mathrm{~h}$ was plotted against the applied current densities.

$$
\text { normalized } \mathrm{COD}=\mathrm{COD}^{*}=100 \times \frac{\mathrm{COD}_{t}}{\mathrm{COD}_{0}}
$$

$\mathrm{COD}_{0}$ and $\mathrm{COD}_{t}$ are the chemical oxygen demands at time $t=0$ and $t \neq 0$ respectively.

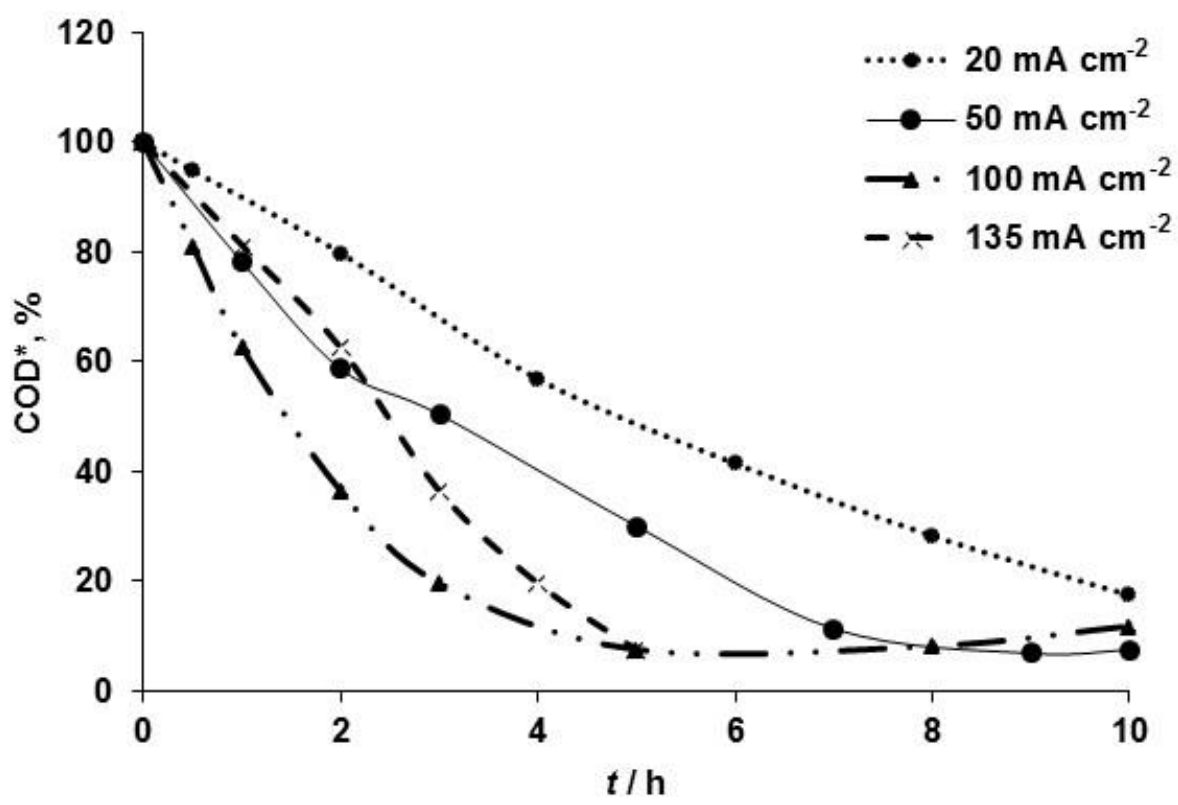

Figure 9. Electrolysis of $1 \mathrm{~g} \mathrm{~L}^{-1}$ amoxicillin on boron doped diamond electrodes in $0.1 \mathrm{M}$ sulfuric acid electrolyte at several current densities. Anode: $B D D$, cathode: Titanium plate, T $=25^{\circ} \mathrm{C} . Q=2.08 \mathrm{~mL} \mathrm{~s}{ }^{-1}$

In fact, as the current increases, the reaction of the mineralization of amoxicillin is faster. However, the trend of the observed COD evolution on BDD clearly shows that the oxidation process is under diffusion control for which a very high current attaining $135 \mathrm{~mA} \mathrm{~cm}^{-2}$ could lower the degradation yield by the occurrence of side reaction which could be attributed mainly to OER. Thus, BDD appears to be a high efficient electrode for the oxidation of the investigated antibiotic. 
According to various reports in that field, BDD was found to promote the mineralization of organics with an efficiency only limited by mass transport control.

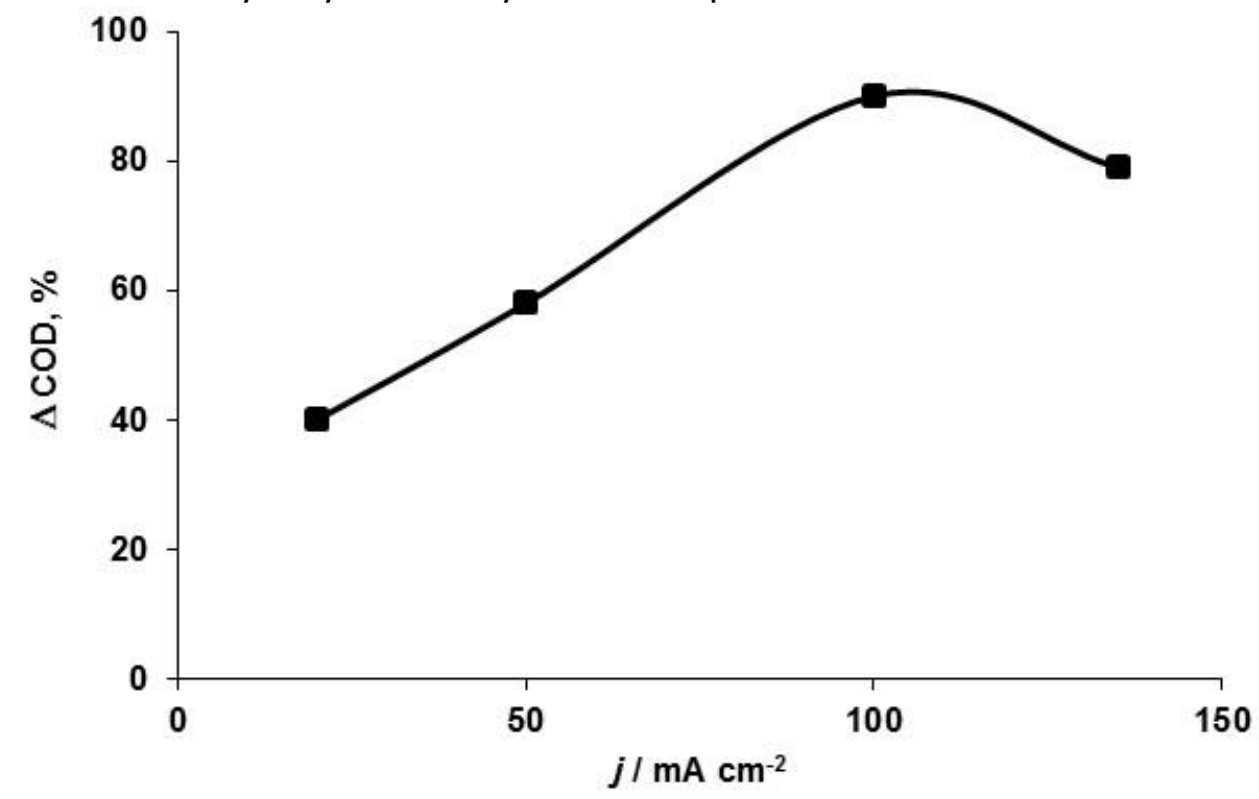

Figure 10: COD removal after $4 \mathrm{~h}$ of electrolyis of $1 \mathrm{~g} \mathrm{~L}^{-1}$ amoxicillin on boron doped diamond electrodes in $0.1 \mathrm{M}$ sulfuric acid electrolyte at several current densities.

Anode: $B D D$, cathode: Titanium plate, $\mathrm{T}=25^{\circ} \mathrm{C}, \mathrm{Q}=2.08 \mathrm{~mL} \mathrm{~s}^{-1}$

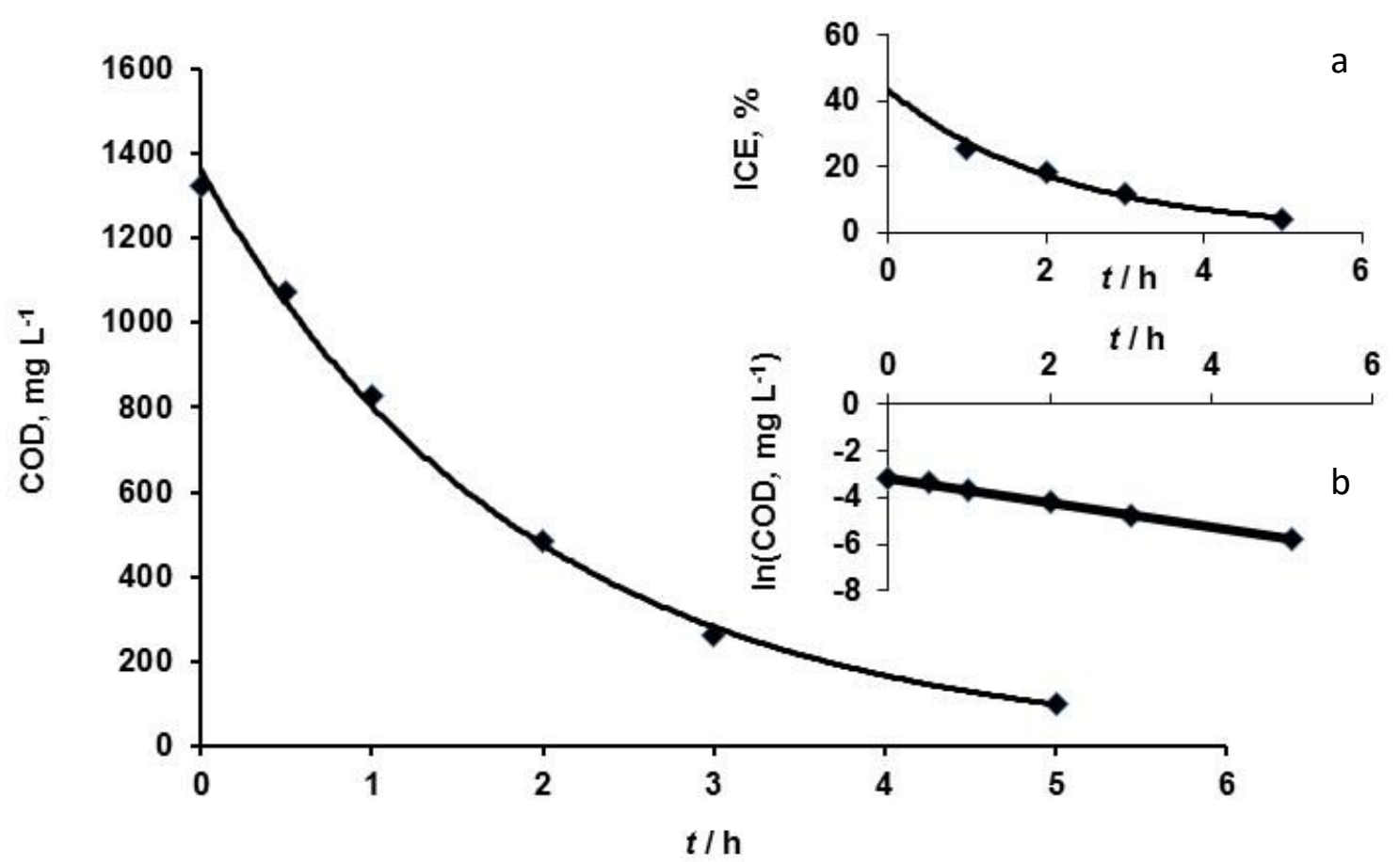

Figure 11. Electrolysis of $1 \mathrm{~g} \mathrm{~L}^{-1}$ amoxicillin on boron doped diamond electrodes in $0.1 \mathrm{M}$ sulfuric acid electrolyte under a current density of $100 \mathrm{~mA} \mathrm{~cm}$, Anode: $B D D$, cathode: Titanium plate, $\mathrm{T}=25^{\circ} \mathrm{C}$, $\mathrm{Q}=2.08 \mathrm{~mL} \mathrm{~s}{ }^{-1} C O D_{0}=1322 \mathrm{ppm}$, inset: $a$ : plot of ICE versus time, $b:$ plot of $\ln (C O D)$ versus time

Figure 11 shows the evolution of COD during the electrochemical oxidation of amoxicillin at constant current density of $100 \mathrm{~mA} \mathrm{~cm}{ }^{-2}$. In the inset the plot of the instantaneous current efficiency (ICE, equation 3 ) versus the electrolysis time $(t)$ was depicted (Figure 11a). In Figure 11b (inset of Figure 11) a curve resulting from the evolution of the logarithm of the chemical oxygen demand versus the electrolysis time was presented. It appears that the ICE is less than $100 \%$ and 
decreases exponentially with time. Such behaviour is in accordance with the model developed by Michaud and coworkers [35].

$$
\mathrm{ICE}=4 F V \frac{\mathrm{COD}_{t}-\mathrm{COD}_{t+\Delta t}}{I \Delta t}
$$

where $\mathrm{COD}_{t}$ and $\mathrm{COD}_{t+\Delta t}$ are the CODs at times $t$ and $t+\Delta t$ (in mol $\left(\mathrm{O}_{2}\right) \mathrm{dm}^{-3}$ ) respectively, $l$ is the current, $A ; F$ is the faraday constant $(96500 \mathrm{C})$ and $V$ is the volume of the electrolyte $\left(\mathrm{dm}^{3}\right)$

Moreover the decrease in ICE indicated that under these working conditions, although amoxicillin mineralization occurs completely, oxygen evolution reaction, which is an undesired parallel reaction, takes place in a high extent that it leads to a decrease in the value of ICE during the oxidation of amoxocillin with time.

In Figure 11, one observed that the decrease of COD with time follows an exponential trend. And the curve of the logarithm of COD with time is linear. The slope of the straigth line is $0.5258 \mathrm{~s}^{-1}, R^{2}=0.998$ ). From those results, the decay of COD during amoxicilin oxidation indicates that the reaction is a pseudo first order with the oxidation rate constant of $0.5258 \mathrm{~s}^{-1}$.

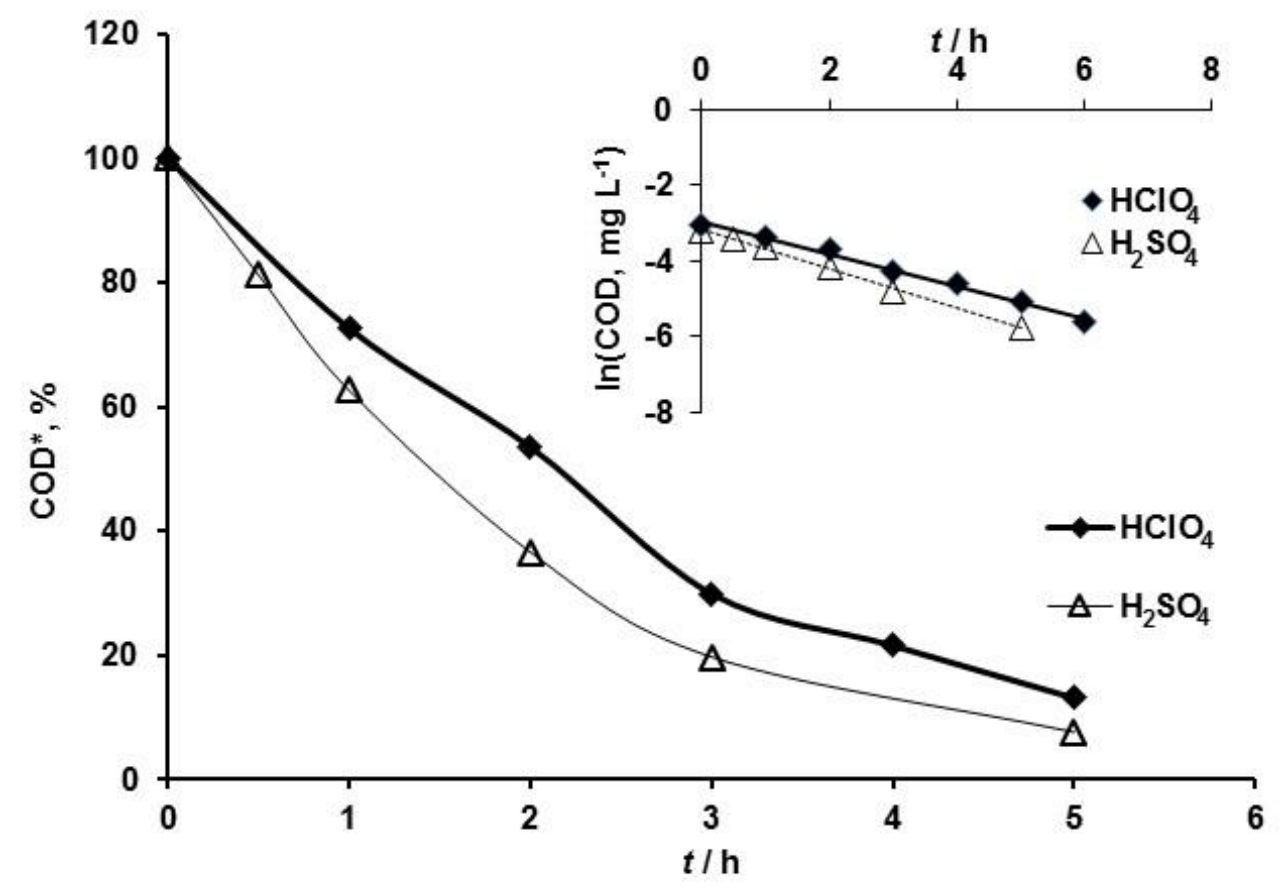

Figure 12. Electrolysis of $1 \mathrm{~g} \mathrm{~L}^{-1}$ amoxicillin on boron doped diamond electrodes in two supporting electrolytes $\left(0.1 \mathrm{M} \mathrm{H}_{2} \mathrm{SO}_{4}\right.$ and $\left.0.1 \mathrm{M} \mathrm{HClO}_{4}\right)$ at $100 \mathrm{~mA} \mathrm{~cm}^{-2}$. Anode: $B D D$, cathode: Titanium plate, $T=25^{\circ} \mathrm{C} . Q=2.08 \mathrm{~mL} \mathrm{~s}^{-1}$.

Figure 12 presents the curves resulting from the electrolysis of amoxicillin in sulfuric acid and in perchloric acid solution under $100 \mathrm{~mA} \mathrm{~cm}^{-2}$. In both acid solutions, COD decreases with time. Two curves follow an exponential decay and linear relationship of the logarithm of COD with time was obtained. The decrease of COD seems to be more rapid in sulfuric acid than in perchloric acid owing to fact that after $5 \mathrm{~h}$ of electrolysis, COD removal is about $87 \%$ and $92 \%$ in perchloric acid and in sulfuric acid, respectively. In both acid solutions, a pseudo first order reaction occurs and the COD removal rate constant determined were $0.5258 \mathrm{~s}^{-1}$ and $0.4304 \mathrm{~s}^{-1}$ in sulfuric acid and in perchloric acid, respectively. The observed difference of the rate of the COD removal in both solutions could result from the differen types of reactive species produced in the solution during 
the electrolysis of amoxicillin. Besides $\mathrm{OH}^{*}$ production, peroxyde is produced in perchloric acid solution while in sulfuric acid solution persulfate is produced. Those oxidants contribute in extending the oxidation of the organic from the vicinity of the electrode surface to the bulk of the solution. The rapid decay of COD in sulfuric acid compared to perchloric acid could be linked to the oxidative performance of persulfate which is higher than that of peroxyde.

During the electrolysis, the absorbance of the samples withdrawn from the simulated wastewater tank was recorded. The result is shown in Figure 13. One observed in Figure 13 that during the first $1 \mathrm{~h}$, an increase of the absorbance is observed. That could be due to the production of intermediates which absorb at the same wavelength as amoxicillin. As the electrolysis is still running, a decrease of the absorbance is observed until total degradation is obtained after $5 \mathrm{~h}$ of electrolysis. In the course of the experiment, the colour of the solution was followed. The colour of the solution became yellow as soon as the electrolysis of amoxicillin started in the current experimental conditions. The intensity of the solution colour increased until the electrolysis time reaches $2 \mathrm{~h}$. After $2 \mathrm{~h}$ of electrolysis, a decrease in the yellow colour intensity was observed and that occured until the end of the electrolysis i.e. $5 \mathrm{~h}$ when the solution became colourless indicating that a complete oxidation of amoxicillin. In fact, the appearance of the yellow colour during the electrolysis could be an indication of the production of intermediates which further undergo oxidation (removal) owing to the desappearence of the observed colour.

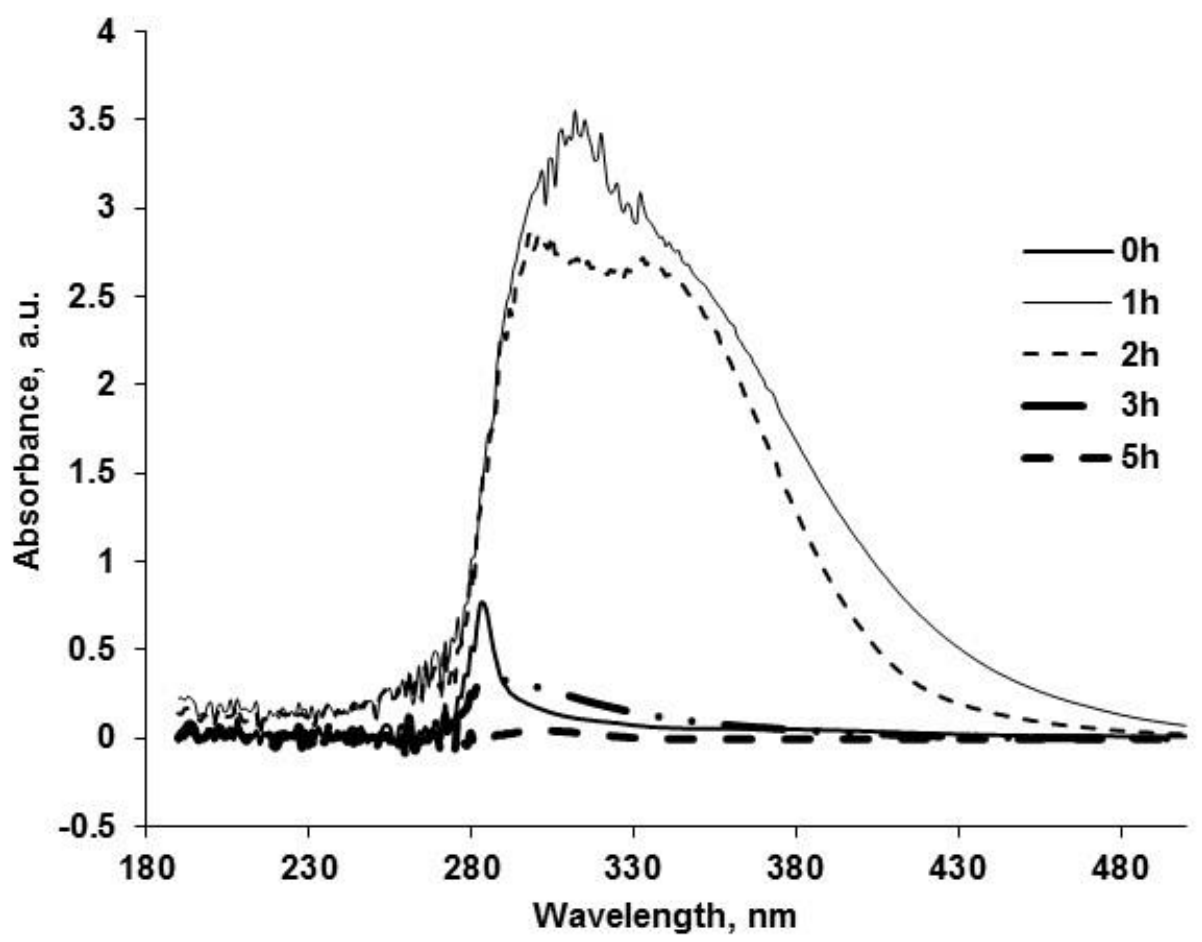

Figure 13. Absorption spectra of amoxicillin samples during amoxicillin electrolysis at $100 \mathrm{~mA}$ $\mathrm{cm}^{-2}$.

The energy consumption was estimated after the electrolysis. During the degradation of amoxicillin, the cell potential was followed and it remains almost constant either in sulfuric acid or in perchloric acid. The cell potentials were about $14.6 \pm 1.0 \mathrm{~V}$ and $5.8 \pm 1.0 \mathrm{~V}$ in sulfuric acid and in perchloric acid solution respectively. The specific energy consumed during the electrolysis of amoxicillin was about $0.096 \mathrm{kWh} \mathrm{COD}^{-1}$ and $0.035 \mathrm{kWh} \mathrm{COD}^{-1}$ in sulfuric acid and in perchloric acid respectively. The COD being expressed in $\mathrm{g} \mathrm{L}^{-1}$. 


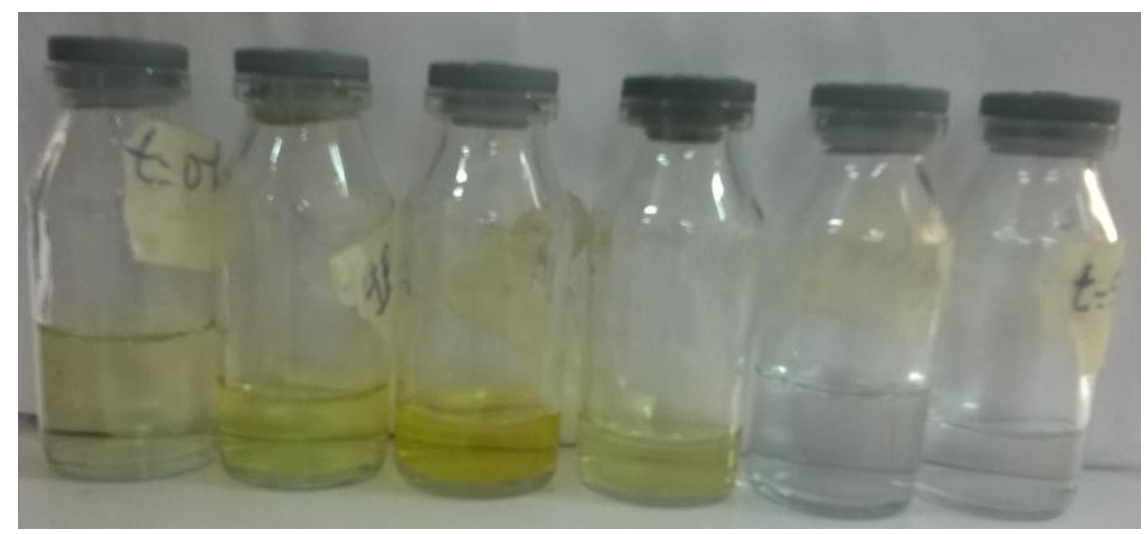

Figure 14. photo of the solution withdrawn from the wastewater tank during electrolysis (from left to rigth : $\mathrm{t}=0 \mathrm{~h} ; 1 \mathrm{~h} ; 2 \mathrm{~h} ; 3 \mathrm{~h} ; 4 \mathrm{~h} ; 5 \mathrm{~h}$ )

At the end, $\mathrm{BaCl}_{2}$ was added to the solution that was withdrawn after $5 \mathrm{~h}$ in case of perchloric acid, and positive reaction occurs indicating the release of $\mathrm{SO}_{4}^{2-}$ in the solution. Finally, complete mineralization of amoxicillin occured in the current experimental conditions. The overall reaction could be:

$$
\mathrm{C}_{16} \mathrm{H}_{19} \mathrm{~N}_{3} \mathrm{O}_{5} \mathrm{~S}+40 \mathrm{H}_{2} \mathrm{O} \rightarrow 16 \mathrm{CO}_{2}+3 \mathrm{NO}_{3}^{-}+\mathrm{SO}_{4}{ }^{2-}+99 \mathrm{H}^{+}+94 \mathrm{e}^{-}
$$

\section{Conclusion}

From this work, it appears that the boron doped diamond electrode (BDD) have a polycrystalline structure. Its surface is composed of grains with sizes between 0.3 and $0.6 \mu \mathrm{m}$. Besides diamond $\left(\mathrm{Csp}^{3}\right)$ crystal, non-diamond carbon impurities $\left(\mathrm{Csp}^{2}\right)$ i.e. graphitic type carbon are found on the BDD surface. As grown boron doped diamond surface chemical bonds are composed of $\mathrm{C}-\mathrm{C}$ and $\mathrm{C}-\mathrm{H}$. The electrochemical characterization of BDD with the ferri/ferrocyanide redox couple showed that the used boron doped diamond electrode is an electrical conducting electrode and a good electrical contact is formed between the silicon substrate and the diamond coating. In sulfuric acid used as a supporting electrolyte, the voltammetric investigation showed a wide potential window of $2.74 \mathrm{~V}$ of water stability on BDD. The electrochemical oxidation of amoxicillin using cyclic voltammetric techniques indicated that a direct oxidation of amoxicillin occured in the electrochemical window of water stability on BDD. That oxidation was catalyzed by the non-diamond carbon impurities such as $\mathrm{Csp}^{2}$ presents at the BDD's grain boundaries. For the bulk electrolysis of the amoxicillin in sulfuric acid under galvanostatic regime in a batch system, amoxicillin undergoes degradation reaching the highest chemical oxygen removal (92\%) under a current density of $100 \mathrm{~mA} \mathrm{~cm}^{-2}$ in sulfuric acid used as supporting electrolyte. The COD decrease follows a pseudo first order reaction with the COD removal rate constant of $0.5258 \mathrm{~s}^{-1}$. Using perchloric acid as supporting electrolyte, $87 \%$ as COD removal yield and $0.4304 \mathrm{~s}^{-1}$ as COD removal rate constant were obtained under $100 \mathrm{~mA} \mathrm{~cm}^{-2}$. The rapid decay of COD in sulfuric acid compared to perchloric acid was linked to the oxidative performance of in situ formed oxidant such as persulfate and peroxyde. The specific energy consumed were about $0.096 \mathrm{kWh} \mathrm{COD}^{-1}$ and 0.035 $\mathrm{kWh} \mathrm{COD}^{-1}$ in sulfuric acid and in perchloric acid respectively after $5 \mathrm{~h}$ of electrolysis. Complete mineralization of amoxicillin was achieved after 5 hours of electrolysis and a release of minerals such as $\mathrm{SO}_{4}^{-2}$ was observed.

Acknowledgements: We greatly thank the Swiss National Funds for its financial support that allowed this work to be carried out. Our Team has received part of the grant IZ01Z0_146919 for 
that work. We thank Prof. Christos Comninellis for supplying us the boron doped diamond electrodes. We also thank Prof. Bakayoko-Ly Ramata, the President of the University Felix Houphouët-Boigny for her help in the realization of that work.

\section{References}

[1] K. G. Koura, A. Garcia, B. Todoégnon, P. Deloron, M. Cot, J.-F. Faucher, Acta Tropica 127(2) (2013) 87-90.

[2] M. A. Lane, A. Zeringue, J. R. Mcdonald, The American Journal of Medicine 127(7) (2014) 657-663.

[3] M. Dosso, E. Bissagnene, M. Coulibaly, H. K. Paye, A. N'douba, N. Guessennd, H. Diaha, S. A. Bouzid, C. A. Koffi, A. M'bengue, P. G. Adou, K. Fofana,A. Kadio, Médecine et Maladies Infectieuses 30(3) (2000) s197-s204.

[4] S. Rodriguez-Mozaz, S. Chamorro, E. Marti, B. Huerta, M. Gros, A. Sànchez-Melsió, C. M. Borrego, D. Barceló, J. L. Balcázar, Water Research 69(1) (2015) 234-242.

[5] C. Chen, J. Li, P. Chen, R. Ding, P. Zhang, X. Li, Environmental Pollution 193 (2014) 94-101.

[6] J. Xu, Y. Xu, H. Wang, C. Guo, H. Qiu, Y. He, Y. Zhang, X. Li,W. Meng, Chemosphere 119 (2015) 1379-1385.

[7] Y. Ma, M. Li, M. Wu, Z. Li, X. Liu, Science of The Total Environment 518-519 (2015) 498-506.

[8] C. Li, J. Chen, J. Wang, Z. Ma, P. Han, Y. Luan,A. Lu, Science of The Total Environment 521522 (2015) 101-107.

[9] M. Colomer-Lluch, W. Calero-Cáceres, S. Jebri, F. Hmaied, M. Muniesa,J. Jofre, Environment International 73 (2014) 167-175.

[10] S.-C. Ricardo, H.-V. María, M. Elisabet, B. José Luis, B. Eloy, Science of The Total Environment 488-489 (2014) 220-227.

[11] N. D. L. Cruz, L. Esquius, D. Gradjean, A. Magnet, A. Tungler, L. F. D. Alencastro,C. Pulgarin, Water Research 47(15) (2013) 5836-5845.

[12] N. D. L. Cruz, J. Giménez, S. Esplugas, D. Gradjean, L. F. D. Alencastro, C. Pulgarin, Water Research 46(6) (2012) 1947-1957.

[13] C. Gagnon, P. Turcotte, S. Trépanier, F. Gagné, P.-J. Cejka, Chemosphere 97 (2014) 86-91.

[14] W. L. D. Silva, M. A. Lansarin, P. R. Livotto, J. H. Z. D. Santos, Powder Technology 279 (2015) 166-172.

[15] M. Quero-Pastor, A. Valenzuela, J. M. Quiroga, A. Acevedo, Journal of Environmental Management 137 (2014) 197-203.

[16] R. A. Torres, V. Sarria, W. Torres, P. Peringer, C. Pulgarin, Water Research 37 (2003) 31183124.

[17] R. Andreozzi, M. Canterino, R. Marotta, N. Paxeus, Journal of Hazardous Materials 122 (2005) 243-250.

[18] D. Mantzavinos, M. Demetriou, E. Hapeshi, D. Partassides, C. Michael, D. Mantzavinos,D. Kassinos, Journal of Chemical Technology and Biotechnology 84 (2009) 1211-1217.

[19] S. Fierro, L. Ouattara, E. H. Calderon, E. Passas-Lagos, H. Baltruschat, C. Comninellis, Electrochimica Acta 54(7) (2009) 2056-2061.

[20] A. Fankhauser, L. Ouattara, U. Griesbach, A. Fischer, H. Pütter, C. Comninellis, Journal of Electroanalytical Chemistry 614(1-2) (2008) 107-112.

[21] D. Santos, M. J. Pacheco, A. Gomes, A. Lopez, L. Ciriaco, Journal of Applied Electrochemistry 43 (2013) 407-416.

[22] J. Iniesta, P. A. Michaud, M. Panizza, G. Cerisola, A. Aldaz, C. Comninellis, Electrochimica Acta 46(23) (2001) 3573-3578.

[23] R. Bellagamba, P. A. Michaud, C. Comninellis, N. Vatistas, Electrochemistry Communications 4(2) (2002) 171-176. 
[24] S. Garcia-Segura, J. Keller, E. Brillas, J. Radjenovic, Journal of Hazardous Materials 283 (2015) 551-557.

[25] A. El-Ghenymy, J. A. Garrido, R. M. Rodríguez, P. L. Cabot, F. Centellas, C. Arias, E. Brillas, Journal of Electroanalytical Chemistry 689 (2013) 149-157.

[26] G. Pastor-Moreno, R. D. Jason, Electrochimica Acta 47(16) (2002) 2589-2595.

[27] M. Hupert, A. Muck, J. Wang, J. Stotter, Z. Cvackova, S. Haymond, Y. Show, G. M. Swain, Diamond and Related Materials 12(10-11) (2003) 1940-1949.

[28] C. Lévy-Clément, N. A. Ndao, A. Katty, M. Bernard, A. Deneuville, C. Comninellis,A. Fujishima, Diamond and Related Materials 12(3-7) (2003) 606-612.

[29] M. A. Kulandainathan, C. Hall, D. Wolverson, J. S. Foord, S. M. Macdonald, F. Marken, Journal of Electroanalytical Chemistry 606 (2007) 150-158.

[30] M. Wang, N. Simon, C. Decorse-Pascanat, M. Bouttemy, A. Etcheberry, M. Li, R. Boukherroub, S. Szunerits, Electrochemistry Communications 12 (2010) 351-354.

[31] E. Dinçkaya, Ö. Kınık, M. K. Sezgintürk, Ç. Altuğ, A. Akkoca, Biosensors and Bioelectronics 26(9) (2011) 3806-3811.

[32] L. Fernández Macía, R. Pintelon, A. Hubin, Journal of Electroanalytical Chemistry 720-21 (2014) 147-155.

[33] E. Mahé, D. Devilliers, C. Comninellis, Electrochimica Acta 50(11) (2005) 2263-2277.

[34] H. Notsu, I. Yagi, T. Tatsuma, D. A. Tryk, A. Fujishima, Journal of Electroanalytical Chemistry 492 (2000) 31-37.

[35] L. Gherardini, P. A. Michaud, M. Panizza, C. Comninellis, N. Vatistas, Journal of the Electrochemical Society 148(6) (2001) D78-D82.

(C) 2015 by the authors; licensee IAPC, Zagreb, Croatia. This article is an open-access article distributed under the terms and conditions of the Creative Commons Attribution license (http://creativecommons.org/licenses/by/4.0/) (cc) EY 